IZA DP No. 8885

Educational Mismatch and Firm Productivity: Do Skills, Technology and Uncertainty Matter?

Benoît Mahy

François Rycx

Guillaume Vermeylen

February 2015 


\title{
Educational Mismatch and Firm Productivity: Do Skills, Technology and Uncertainty Matter?
}

\author{
Benoît Mahy \\ HumanOrg, University of Mons \\ François Rycx \\ Université Libre de Bruxelles (SBS-EM, CEB and DULBEA) \\ and IZA
Guillaume Vermeylen
HumanOrg, University of Mons
and IWEPS \\ Discussion Paper No. 8885
February 2015 \\ IZA \\ P.O. Box 7240 \\ 53072 Bonn \\ Germany \\ Phone: +49-228-3894-0 \\ Fax: +49-228-3894-180 \\ E-mail: iza@iza.org
}

Any opinions expressed here are those of the author(s) and not those of IZA. Research published in this series may include views on policy, but the institute itself takes no institutional policy positions. The IZA research network is committed to the IZA Guiding Principles of Research Integrity.

The Institute for the Study of Labor (IZA) in Bonn is a local and virtual international research center and a place of communication between science, politics and business. IZA is an independent nonprofit organization supported by Deutsche Post Foundation. The center is associated with the University of Bonn and offers a stimulating research environment through its international network, workshops and conferences, data service, project support, research visits and doctoral program. IZA engages in (i) original and internationally competitive research in all fields of labor economics, (ii) development of policy concepts, and (iii) dissemination of research results and concepts to the interested public.

IZA Discussion Papers often represent preliminary work and are circulated to encourage discussion. Citation of such a paper should account for its provisional character. A revised version may be available directly from the author. 
IZA Discussion Paper No. 8885

February 2015

\section{ABSTRACT}

\section{Educational Mismatch and Firm Productivity: Do Skills, Technology and Uncertainty Matter?}

The authors provide first evidence on whether the direct relationship between educational mismatch and firm productivity varies across working environments. Using detailed Belgian linked employer-employee panel data for 1999-2010, they find the existence of a significant, positive (negative) impact of over- (under-)education on firm productivity. Moreover, their results show that the effect of over-education on productivity is stronger among firms: (i) with a higher share of high-skilled jobs, (ii) belonging to high-tech/knowledge-intensive industries, and (iii) evolving in a more uncertain economic environment. Interaction effects between under-education and working environments are less clear-cut. However, economic uncertainty is systematically found to accentuate the detrimental effect of under-education on productivity.

JEL Classification: J21, J24

Keywords: educational mismatch, productivity, linked employer-employee panel data, working environments

Corresponding author:

François Rycx

SBS-EM, Université Libre de Bruxelles

CP 114/02, Avenue F.D. Roosevelt, 50

B-1050 Brussels

Belgium

E-mail: frycx@ulb.ac.be

\footnotetext{
* The authors are most grateful to Statistics Belgium for giving access to the data. Funding for this research was provided by the Walloon Region (IPRA Research Grant, IWEPS). François Rycx gratefully acknowledges financial support from the Belgian Federal Science Policy Office (BELSPO): SPP Politique Scientifique, programme "Société et Avenir", Employment, Wage Discrimination, and Poverty, Research contract TA/00/046/EDIPO.
} 


\section{Introduction}

Over the past couple of years, our advanced economies have been facing a constant rise in the workers' level of education. For instance, the tertiary attainment level in the EU27 countries increased from 22.4\% in 2000 to 34.6\% in 2011 (European Commission 2012). Moreover, the European Union (2009) aims to reach a proportion of $40 \%$ of tertiary educated workers aged between 30 and 34 by 2020. Educational mismatch (Freeman 1976) appears if this increasing level of education is not matched by jobs requiring increasing skills. It represents the inadequacy between the workers' attained level of education and the level of education required for their jobs. Workers are then considered either over-educated if their level of attained education is higher than the level of education required for their jobs, or undereducated in the opposite case. Therefore, over- and under-education are the two educational mismatch variables we will consider in this paper. The European Union (2012) shows that educational mismatch is an important phenomenon that has concerned $36 \%$ of workers in the EU27 countries over the decade 2001-2011, with significant variations from one European country to the other. Moreover, roughly 30\% of tertiary educated workers were over-educated in 2009. Over-education can also represent a cost for three economic actors involved (McGuinness 2006): for individuals themselves, when over-educated workers earn less than their former classmates in jobs that match their level of education; for firms, when overeducated are less productive than adequately educated workers; and for the entire economy, when financing excessive levels of education causes inefficiency.

Educational mismatch therefore appears to be an important issue, the effects of which need to be investigated (Mavromaras and McGuinness 2012; Sattinger and Hartog 2013). Although findings on the impact of educational mismatch on wages are quite consistent, existing evidence of the effect of educational mismatch on firm productivity goes in multiple, different directions (Hartog 2000; Sattinger, 2012). The first trend of research relies on human capital theory, which infers the effects of over- and under-education on productivity through their effects on wages (Battu et al. 1999; Duncan and Hoffman 1981; Rumberger 1987; Mavromaras et al. 2010; Sicherman 1991; Van der Meer 2006). The second trend studies the influence of educational mismatch on job satisfaction and other correlates of workers' productivity (Büchel 2002; Green and Zhu 2010; Hersch 1991; Tsang 1987; Tsang et al. 1991; Verhaest and Omey 2006, 2009).

However, these two trends of research lead to different conclusions. The first most often shows that over-educated workers are more productive than their adequately educated 
colleagues in similar jobs, whereas the second provides ambiguous predictions. In addition, these two approaches suffer from several methodological limitations. As for human capital explanations, the idea that the effect of education on wages can be transposed as such on productivity should most probably not be assumed lightly (Mortensen 2003). Turning to job satisfaction, empirical results show that it is only correlated to job performance at a $30 \%$ level (Judge et al. 2001). It is thus quite misleading to focus only on job satisfaction to estimate the productivity effects of educational mismatch. The common main methodological shortcoming of these trends of research is that they do not address the effect of educational mismatch on productivity as such, but always indirectly. As Hartog (2000) explained, it would be interesting to know the direct effect of over- and under-education on productivity, rather than indirectly through wages, job satisfaction, and other correlates.

To our knowledge, the studies of Kampelmann and Rycx (2012) and Grunau (2014) are the first so far to directly address the effect of over- and under-education on firm productivity as such. However, their conclusions leave the door open for further developments. An important avenue for research is to determine under what conditions educational mismatch has positive effects and under what conditions it has negative effects. It is most probably appropriate to assume that the relationship between educational mismatch variables and firm productivity may depend on specific working environments of the firm. As a straight, simple example, it is easy to imagine that an over-educated worker with a $\mathrm{PhD}$ in mathematics could add value to the financial department of a bank or to a high-tech company operating in a constantly changing environment. In contrast, the same over-educated worker employed in a traditional retail store or cleaning company might be less productive than his adequately educated peers, due to frustration (i.e., a lower level of job satisfaction).

The aim of this paper is to provide first evidence on whether the direct relationship between educational mismatch and firm productivity varies across working environments. More precisely, we explore the way working environments, differentiated by (i) the level of skills required by the job, (ii) the degree of technological/knowledge intensity, and (iii) the uncertainty of the economic context, may influence the relation between educational mismatch variables and productivity. In order to address these issues, we rely on detailed Belgian linked employer-employee panel data covering the period 1999-2010, use an ORU (Over-, Required, and Under-education) specification aggregated at firm level and consider the average firm-level value added per worker as dependent variable. We thus estimate how mean years of over- and under-education within firms affect the productivity of these firms 
(conditional on mean years of required education) across different working environments. The richness of our dataset allows us to control for a wide range of worker and firm characteristics. It also enables us to address important methodological issues such as firmlevel invariant heterogeneity, reverse causality, and dynamics in the adjustment process of productivity. To do so, we rely on both the dynamic system-GMM estimator developed by Blundell and Bond (1998) and the structural approach suggested by Levinsohn and Petrin (2003).

\section{Review of the Literature}

\subsection{Educational Mismatch and Firm Productivity}

From a microeconomic point of view, two different approaches are considered in the literature on the effect of educational mismatch on firm productivity. The first one relies on human capital theory (Becker 1964). It states that education allows developing skills that make workers more productive, and that the gap in earnings should reflect these different levels of productivity. Consequently, the effect of educational mismatch on productivity could be estimated through its impact on wages. This has been done by Rumberger (1987), who shows, on the basis of U.S. cross-sectional data, that the impact of a year of over-education on wages is positive but lower than the impact of a year of required education. Therefore, he suggests that "additional schooling is not completely unproductive, but simply that jobs constrain the ability of workers to fully utilize the skills and capabilities they acquire in school” (Rumberger 1987: 46). Other studies, some of which control for workers' fixed unobserved heterogeneity and/or field of education, also found that over- (under-)educated workers earn more (less) than their adequately educated peers. This implies, according to human capital theory, that over- (under-)education increases (decreases) workers' productivity (see e.g., Battu et al. 1999; Dolton and Silles 2008; Duncan and Hoffman 1981; McGuinness and Sloane 2011; Sicherman 1991; Van der Meer 2006).

A second strand of the literature examines the impact of educational mismatch on job satisfaction and other correlates of workers' productivity (such as absenteeism, shirking or turnover). The standard hypothesis here is that over-educated workers, frustrated by using fewer skills than they have, could be less satisfied, more absent, and sicker than their adequately educated peers (Vroom 1964). The consequence would be that firms are reluctant to hire over-educated workers because of their negative impact on firm productivity. 
However, empirical results go in different directions. On the one hand, Hersch (1991) shows that over-educated workers are less satisfied than the other workers, and that over-educated male workers are more ready to quit their jobs. This is confirmed by Tsang et al. (1991), except for the relationship estimated for over-educated female workers. Verhaest and Omey (2006), using Belgian data on Flanders covering the period 1999-2002, find that overeducated workers have a higher turnover, but they cannot validate the hypothetic impact of over-education on job satisfaction. However, using the same (but extended) dataset on Flanders, they find, in 2009, a significant negative impact of over-education on job satisfaction but also find that the negative consequence of over-education on job satisfaction decreases with the number of years of experience. Tsang (1987) investigates the effect of over-education on job satisfaction but also constructs a firm-level job-satisfaction index in his study and estimates its effect on firm productivity through a Cobb-Douglas production function. He finds that over-education impacts job satisfaction negatively, but also that job satisfaction is positively and significantly correlated to output, concluding that over-education impacts the worker's productivity negatively. On the other hand, according to the results of Büchel (2002), there is no significant relation between over-education and job satisfaction. He even finds that over-educated workers are healthier, more work- and career-minded, and stay longer in the same firm.

These two approaches thus lead to different conclusions: while human capital theory suggests that over-educated workers should be more productive, job satisfaction studies don't necessarily come to the same end. Moreover, the two approaches suffer from methodological limitations. For example, human capital theory supposes that the level of education influences marginal productivity and wages in the same way. But the relationship could be more complex than that. Spence (1973) exposes signalling theory (screening model) in which productivity is linked to factors such as family background, worker's history, or even talent. According to this theory, education is just used as a signal for an applicant to prove his capabilities to the employer. Moreover, wages cannot be linked strictly to productivity in every case. That is, in non-competitive models of wage determination such as rent-sharing, collective bargaining, discrimination or monopsony models, wages do not necessarily reflect marginal productivity, and workers with similar productive characteristics are found to receive different wages (Blanchflower and Bryson 2010; Manning 2003; Mortensen 2003). As for job satisfaction theory, many studies seem to forget that job satisfaction is not the only factor influencing productivity through education (Judge et al., 2001). Even if over-educated 
workers are less satisfied with their jobs, and even if someone unsatisfied is less productive as such, these workers might have additional skills and capabilities acquired during schooling that allow to compensate the effect of job satisfaction on productivity.

However, the main shortcoming of these studies is that they all investigate the effect of educational mismatch on productivity in an indirect way. Hartog (2000) already noted this issue and stated that it would be interesting to know the direct effect of over- (under-) education on productivity instead of its indirect effect through wages, job satisfaction, or other related characteristics of workers. As far as we know, direct estimates of the impact of ORU variables (Over-, Required, and Under-education) on firm productivity (assessed through the value added per capita) have so far only been provided by Kampelmann and Rycx (2012) and Grunau (2014). While both studies report that undereducated workers impair firmlevel productivity, they differ as regards the impact of over-education (it is found to be significantly positive in the former study and insignificant in the latter). Additional work is thus needed to improve our understanding of this nexus. Moreover, their results leave the door open for further developments.

\subsection{Working Environments}

An important research question that has so far not been investigated is whether the impact of educational mismatch on firm productivity varies across working environments. The objective of this paper is to provide first evidence on this issue by exploring how working environments, differentiated by (i) the level of skills required by jobs, (ii) the degree of technological/knowledge intensity, and (iii) the uncertainty of the economic context, may influence the relationship between educational mismatch variables and productivity.

\subsubsection{Skills Required by the Job}

The first environment assessed concerns skills required by the job. Brown (1990) explains that workers' productivity is more "workers' quality” sensitive in jobs requiring higher skills. From this point of view, over-education can influence productivity through its impact on workers' quality.

More precisely, it can first improve it thanks to increased externalities between workers themselves. That is, relying on human capital theory, Booth and Snower (1996) state that when workers acquire skills, not only are they more productive, but there is also a positive effect on their peers' productivity. This statement confirms Marshall's (1890) intuition that 
interactions between workers create learning opportunities that increase productivity, and that the larger the share of more (over-) educated workers, the more externalities will be generated between workers, i.e., the higher the average workers’ quality will be.

Over-education can also improve workers' quality thanks to better unobservable worker characteristics associated to higher levels of education. Weiss (1995) shows that more (over-) educated workers possess better unobservable characteristics that increase their productivity, such as a better work attitude or a lower propensity to turnover. Barrick and Mount (1991) also show that conscientiousness, as a synthetic measure of behaviours such as motivation and diligence, is a good predictor of job performance. Hogan and Ones (1997) highlight that workers with higher conscientiousness scores are hard-working, careful, ambitious, and thus more productive than those with lower conscientiousness scores, who tend to be more lazy, careless, unambitious, etc. Barrick and Mount (1991) further attest that conscientiousness is highly correlated with measures of educational achievement, suggesting that over-education should favour workers' quality.

But workers' quality could also be negatively affected by over-education. As mentioned in job satisfaction theory, more (over-) educated workers could be less satisfied in their working lives than other workers because they have to work below their actual level of skills. This lack of satisfaction could, in turn, cause over-educated workers to be more absent or sicker, indicating lower level of workers' quality and inducing lower productivity (Hersch 1991). Furthermore, Caplan (2003) questions the expected positive relationship between higher education and workers' quality through some dimensions of higher conscientiousness, in the sense that higher intelligence does not necessarily impact conscientiousness and, thereby, workers' quality.

\subsubsection{Technology/Knowledge Intensity}

The second environment refers to the technological and knowledge environment of the firm. Nelson and Phelps (1966) develop the notion of adaptability. They propose two specific dimensions of education: the ability to adapt to technological changes and the ability to innovate. Krueger and Kumar (2004) follow this idea by assuming that education allows to reduce the probability that workers would suffer a loss in productivity from the introduction of a new technology. In that way, over-educated workers could be relatively more productive in a high-tech/knowledge job than in a low-tech/knowledge job because of their better capacities (i.e., their adaptability) to interact within a high-tech/knowledge environment, 
which corresponds to more changing and more challenging conditions. In turn, hightech/knowledge firms should devote more latitude to over-educated workers in order to be as competitive as possible in these more challenging environments. In other words, they should be more inclined to develop the innovation capabilities of their workers. For these reasons, the opportunity for over-educated workers to develop their creativity and innovation capacity, and thereby the relation between their capacities and their productivity, should be favoured when they work in high-tech/knowledge intensive firms.

Nevertheless, this expected positive effect of high-tech/knowledge firms on the relation between over-education and productivity needs to be qualified. Some authors such as Bartel and Sicherman (1998) or Autor et al. (1998) distinguish two types of technological changes, depending on the extent to which the new technology complements or substitutes skills acquired through schooling. They find that a positive relationship between human capital and workers' productivity appears when the introduction of a technology complements skills already acquired by workers during their schooling. But, when the introduction of a new technology replaces skills acquired during schooling, it may also create a decrease in the demand for higher education and, in turn, lead to a negative impact of education on productivity, pushing workers to focus on on-the-job training rather than on formal education. As such, this argument suggests that the impact of over-education on productivity might depend on whether a newly implemented technology complements or substitutes skills.

\subsubsection{Uncertainty of the Firm's Economic Environment}

The impact of educational mismatch variables on productivity could also be different when the uncertainty of the economic context is taken into account. We could first assume a higher impact of over-education on productivity when firms are evolving in a more uncertain environment. To support this idea, we rely on the Bandura's (1986) self-efficacy concept coming from the social cognitive theory, referring to "people's judgments of their capabilities to organize and execute courses of action required for attaining designated types of performances” (Bandura 1986: 391). This concept is used by McQuaid et al. (2012), who suggest that lower educated workers believe that their limited skills could reduce their capability to make a successful career. Conversely, the more educated the workers, the higher their level of self-efficacy should be. Therefore, when firms operate in more uncertain environments, a higher level of self-efficacy should be more important in order for these firms 
to be competitive. And the level of productivity of over-educated workers should therefore be favoured in such circumstances.

This positive relation is also supported when relying on the job competition model developed by Thurow (1975, 1979). This model states that productivity is tied to the characteristics of the jobs rather than those of the workers, and that variables such as education are used by employers in order to take their hiring decisions. According to costs minimising considerations, the worker's position in the queue is then determined by his cost in terms of training, and education then conditions the expected cost of training to be supported by the firm: the more educated the employee, the less he has to be trained. These cost minimising considerations also apply in case of uncertainty, when job characteristics change often. Stankiewics (2004) suggests in this case that employers consider not only the capacity to meet the requirements of the actual job, but also the capacity of the worker to adapt to moving circumstances in their hiring decision. And the higher expected level of adaptability of over-educated workers should then be more useful in case of uncertainty: they could faster implement the changes needed, thus leading to higher levels of productivity at lower training costs. Moreover, Bulmahn and Kräkel (2002) highlight that over-educated workers are helpful in contexts of economic uncertainty, as they can offer the improvising and ad hoc solutions more quickly than other workers, which could in turn also explain their higher levels of productivity.

But the more important (positive) relationship between productivity and over-education in more uncertain environments is not necessarily always expected to be encountered. In the case of tournaments between workers (Lazear and Rosen 1981), firms award prizes (i.e., bonuses or promotions) according to workers' relative performances. Following human capital theory, the more educated the worker, the higher his likelihood to obtain the highest prize. However, the increasing role of luck associated to uncertain environments can lead to a reduction in the worker's level of effort to win a prize and, subsequently, a reduction of his productivity which can be stronger for more (over-) educated workers. Researchers try to figure out this phenomenon. Mahy et al. (2011), for instance, mention that a stronger reduction in over-educated workers' productivity can come from the fact that they would not compete as hard as before to win a prize when they have less influence on their output in case of higher uncertainty. Also, Lazear (1989) states that there could appear unexpected consequences in tournament models, that is, more educated workers could choose to use sabotage techniques in order to maximize their chances to win the highest prize, which in turn 
distracts them from their productivity objectives. The drop in productivity may thus be stronger among over-educated workers, who are to a bigger extent concerned by tournaments and by their drifts.

\section{Methodology}

\subsection{Overall Specification}

We basically find in the literature three ways to measure the required education for a job and the incidence of educational mismatch. The first one, called the objective measure or job analysis approach is based on the evaluation by professional analysts of the level and type of education that is required for a specific job. The American Dictionary of Occupational Titles (DOT) is an example of such approach. The second approach, called subjective or selfassessment approach, requires the employee/employer to determine the type and level of formal education that is necessary for the achievement of the tasks associated with a given job. This measurement thus rests on employee and/or employer surveys. The third approach, called empirical or realized matches approach, derives the required level of education for a job from what workers in the corresponding job or occupation usually have attained. The required education is then generally computed on the basis of the mode of the education in a given occupation.

Each measure has its own advantages and weaknesses (for a detailed discussion see e.g. Hartog (2000)). For instance, the job analysis approach is appealing because it is based on clear definitions and explicit measurement instructions. However, because of the cost and difficulty of this exercise, classifications based on job analysis are only published from time to time. Moreover, given that technological progress is likely to affect rapidly the content and complexity of jobs, classifications become fast outdated. Another point is that there is no such classification for Belgium and the use of a foreign one would probably create important measurement errors given that job classifications and requirements vary across countries. The second approach, based on workers' self-assessment, interestingly relies on local up-to-date information. However, it suffers from the fact that it is not based on rigorous instructions. In particular, respondents may overstate the requirements of their own job. It also typically leads to a downward biased proportion of under-educated workers. Finally, the realized matches approach has the advantage that it can be implemented easily and on a regular basis. Moreover, in contrast to the self-assessment approach, it enables to estimate more easily how 
much a worker is over- or under-educated. However, realized matches are criticized because of their endogenous definition. The point is that the required education is likely to be influenced by the extent of over- and under-education.

Overall, it is impossible to say that one measure is strictly better than the others and in practice the choice of a measure is often dictated by data availability (McGuinness, 2006). Given the feature of ours, we use realized matches in this paper. Thus, we compute the required level of education for a given job by taking the mode of workers' years of education within each ISCO 3-digit occupation (113 categories). ${ }^{1}$ A worker is then defined as over(under-) educated if his attained years of education are higher (lower) than those required, i.e. observed, in his occupation.

To examine the impact of educational mismatch variables on firm productivity, we use an ORU specification aggregated at firm level. More precisely, we estimate the following firmlevel productivity equation:

$$
\begin{aligned}
\ln V A_{j, t}= & \beta_{0}+\beta_{1}\left(\ln V A_{j, t-1}\right)+\left[\frac{1}{m_{j, t}}\left(\beta_{2} \sum_{i=1}^{m_{j, t}} O_{i, j, t}\right)+\left(\beta_{3} \sum_{i=1}^{m_{j, t}} R_{i, j, t}\right)+\left(\beta_{4} \sum_{i=1}^{m_{j, t}} U_{i, j, t}\right)\right] \\
& +X_{j, t} \beta_{5}+Z_{j, t} \beta_{6}+\gamma_{t}+v_{j, t}
\end{aligned}
$$

In this equation, $V A_{j, t}$ is the productivity of firm $j$ at year $t$, measured by the average value added per worker; $m_{j, t}$ is the number of workers employed in firm $j$ at year $t ; R_{i, j, t}$ is the required years of education for the worker's job $i$ in firm $j$ at year $t$, measured by the mode of years of education in worker's $i$ occupation at ISCO (International Standard Classification of Occupations) 3-digit level at year $t ; O_{i, j, t}=\left(\right.$ Attained education $\left._{i, j, t}-R E Q_{i, j, t}\right)$ if $>0,0$ otherwise; $U_{i, j, t}=$ (Attained education $\left._{i, j, t}-R E Q_{i, j, t}\right)$ if $<0,0$ otherwise; Attained education ${ }_{i, j, t}$ is the number of years of schooling attained by worker $i$ in firm $j$ at year $t ; X_{j, t}$ is a vector representing aggregated characteristics of workers in firm $j$ at year $t$ : the share of the workforce that has at least 10 years of tenure, the fractions of workers respectively younger

\footnotetext{
${ }^{1}$ The workers' educational attainment is available in 7 categories in our dataset. This information, reported by firms' human capital departments (on the basis of their registers), has been transformed in years of education. To this end, we applied the following rule: (i) primary education: 6 years of education; (ii) lower secondary education: 9 years of education; (iii-iv) general, technical and artistic upper secondary education: 12 years of education; (v) higher non-university education, short: 14 years of education; (vi) university and non-university education, long: 16 years of education; (vii) postgraduate education: 17 years of education.
} 
than 30 and older than 49 , and the shares of women, blue-collar and part-time workers; $Z_{j, t}$ is a vector containing firm $j$ characteristics at year $t$ : the sectorial affiliation ( 8 dummies), the age and size (number of workers) of the firm, the conditional dispersion in hourly wages, and the level of wage bargaining ( 1 dummy); $\gamma_{\mathrm{t}}$ is a set of 11 year dummies; and $v_{\mathrm{j}, \mathrm{t}}$ is the error term.

This equation investigates the relationship between average years of over-, required and under-education within firms and the productivity of the latter, when controlling for year dummies and mean worker and firm characteristics. ${ }^{2}$ The inclusion of the lagged dependent variable among the regressors accounts for the potential state dependence of firm productivity and aims to improve the parameters of interest in our preferred specifications.

\subsection{Interactions with Working Environments}

We make the impact of educational mismatch on firm productivity interact with working environments. To this end, we estimate equation (1) each time for two distinct groups of firms from our panel, according to the working environment to be investigated. We then compare estimates between the two groups, environment by environment.

\subsubsection{Skills Required by the Job}

To test whether the relationship between education and productivity first depends on the skills required by the job, we compose two groups of firms, the first one of firms with lower required skills. We assume that the firm belongs to this first group if it presents a proportion of low-ability occupations (occupations that fall into categories 7 to 9 of ISCO-88 and ISCO08 nomenclatures) larger than the mean of the whole sample. The remaining firms belong to the group of firms with higher required skills.

\subsubsection{Technology/Knowledge Intensity}

We compose two groups of firms, distinguished by their levels of technological/knowledge intensity, following a taxonomy developed by Eurostat (2012), the HT/KIS nomenclature. This nomenclature gives the Nace 2- or 3-digit code, according to which some firms can be classified as high-tech/knowledge and others as low-tech/knowledge. This indicator covers

\footnotetext{
${ }^{2}$ Note that: $\frac{1}{m_{j, t}}\left(\sum_{i=1}^{m_{j, t}} O_{i, j, t}+\sum_{i=1}^{m_{j, t}} R_{i, j, t}+\sum_{i=1}^{m_{j, t}} U_{i, j, t}\right)=\frac{1}{m_{j, t}} \sum_{i=1}^{m_{j, t}}$ Attained $_{i, j, t}$, i.e., the sum of the average years of required, over-, and under-education in firm $j$ at time $t$ is equal to the average years of education attained by the workers employed in firm $j$ at time $t$.
} 
industrial and service-oriented firms. Manufactures are aggregated according to technological intensity based on the R\&D expenditure, i.e., high-technology and medium high-technology in the first group, medium low-technology and low-technology in the second; services are aggregated according to their share of tertiary educated persons, i.e., knowledge-intensive services in the first group, and less knowledge-intensive services in the second. So the group of firms considered as high-tech/knowledge intensive belongs to sectors that are high-medium tech/knowledge intensive (HT/KIS), while the second group of firms considered as low-tech belongs to sectors that are medium-low tech/less knowledge intensive (non-HT/KIS).

\subsubsection{Uncertainty of the Firm's Economic Environment}

In order to divide our sample between groups of firms that belong to less or to more uncertain economic environments, we use an indicator proposed by Mahy et al. (2011), i.e., the mean rate of bankruptcy at a NACE 3-digit level supplied by Statistics Belgium. The first subset gathers firms belonging to sectors registering a higher mean rate of bankruptcy than the mean of the whole sample, while the second gathers firms belonging to sectors registering lower bankruptcy.

\subsection{Estimation Techniques}

Equation (1) has been estimated with four different methods: pooled ordinary least squares (OLS), a fixed-effects (FE) model, the generalized method of moments (GMM) estimator developed by Arellano and Bover (1995) and Blundell and Bond (1998), and a more structural approach suggested by Levinsohn and Petrin (2003, hereafter LP). The OLS estimator with standard errors robust to heteroscedasticity and serial correlation is based on the cross-section variability between firms and the longitudinal variability within firms over time. However, this OLS estimator suffers from a potential heterogeneity bias because firm productivity can be related to firm-specific, time-invariant characteristics that are not measured in micro-level surveys (e.g., an advantageous location, firm-specific assets such as patent ownership, or other firm idiosyncrasies).

One way to remove unobserved firm characteristics that remain unchanged during the observation period is to estimate a FE model. However, neither pooled OLS nor the FE 
estimator address the potential endogeneity of our explanatory variables. ${ }^{3}$ Yet, there might be some cyclical 'crowding out', namely a process by which highly educated workers take jobs that could be occupied by less educated ones during recessions, because of excess labour supply. This assumption suggests that mean years of over-education within firms may increase as a result of a lower labour productivity (and vice versa). To control for this endogeneity issue, in addition to state dependence of firm productivity and the presence of firm fixed effects, we estimate equation (1) with the dynamic system GMM (GMM-SYS) and LP estimators, respectively.

The GMM-SYS approach boils down to simultaneously estimating a system of two equations (respectively in level and in first differences) and relying on internal instruments to control for endogeneity. More precisely, ORU variables ${ }^{4}$ are instrumented by their lagged levels in the differenced equation and by their lagged differences in the level equation. The implicit assumption is that differences (levels) in (of) productivity in one period, although possibly correlated with contemporaneous differences (levels) in (of) ORU variables, are uncorrelated with lagged levels (differences) of the latter. Moreover, differences (levels) in (of) ORU variables are assumed to be reasonably correlated to their past levels (differences).

As an alternative to the GMM-SYS method, Olley and Pakes (1996) have developed a consistent semi-parametric estimator. This estimator, particularly well-suited for panels with small $t$ and big $N$, controls for endogeneity by using the employer's investment decision to proxy for unobserved productivity shocks. The intuition is that firms respond to time-varying productivity shocks observed by managers (and not by econometricians) through the adjustment of their investments. Put differently, profit-maximizing firms react to positive (negative) productivity shocks by increasing (decreasing) their output, which requires more (less) investments (or intermediate inputs, see below). The OP estimation algorithm relies on the assumptions that there is only one unobserved state variable at the firm level (i.e., its productivity) and that investments increase strictly with productivity (conditional on the values of all state variables). This monotonicity condition implies that any observation with zero investment has to be dropped from the data, which generally leads to a sharp decrease in sample size and is hence likely to create a sample selection issue.

\footnotetext{
${ }^{3}$ Expected biases associated with OLS and the relatively poor performance and shortcomings of the FE estimator in the context of firm-level productivity regressions are reviewed in Van Beveren (2012).

${ }^{4}$ By 'ORU variables', we mean ORU variables and other endogenous input factors.
} 
To avoid this drawback, Levinsohn and Petrin (2003) use intermediate inputs (i.e., inputs such as energy, raw materials, semi-finished goods, and services that are typically subtracted from gross output to obtain added value) rather than investments as a proxy for productivity shocks. Given that firms typically report positive values for intermediate inputs each year, most observations can be kept with the LP approach. An additional argument for using intermediate inputs rather than investments is that the former may adjust more smoothly to the productivity term than the latter, especially if adjustment costs are an important issue. For instance, "if adjustment costs lead to kink points in the investment demand function, plants may not respond fully to productivity shocks, and some correlation between the regressors and the error term can remain” (Petrin et al. 2004: 114). Intermediate inputs would thus provide a better proxy for unobserved productivity shocks. In the basic LP model, labour is a fully variable input, whereas capital is a fixed input. Given our focus, the variable inputs in our setup include the first moments of workforce characteristics. Assuming that intermediate inputs depend on capital and the unobservable productivity shocks, this relationship can be solved for the productivity term (Ilmakunnas and Ilmakunnas 2011). When relying on the LP estimation algorithm, standard errors are computed using a bootstrap approach taking the panel structure of the data into account (Petrin et al. 2004).

\section{Data and Descriptive Statistics}

\subsection{Data}

We use a combination of two large datasets covering the years 1999-2010. The merger of the two datasets has been realized by Statistics Belgium, using the firms' social security numbers. The first is the "Structure of Earnings Survey" (SES), carried out by Statistics Belgium. It covers all firms that are operating in Belgium, employ more than 10 workers and have economic activities within sections $\mathrm{B}$ to $\mathrm{N}$ of the NACE Rev. 2 nomenclature. This survey gathers information on firms' characteristics (e.g., sector, number of workers, level of collective wage bargaining) as well as information on workers' characteristics (e.g., age, education, tenure, gross earnings, paid hours, sex, occupation). However, the SES does not provide any financial information. It has thus been merged with a firm-level survey, namely the "Structure of Business Survey" (SBS), also carried out by Statistics Belgium. This survey provides financial information (e.g., firm-level value added and gross operating surplus per 
worker). The coverage of the SBS is not the same as that of the SES, as it does not cover the entire financial sector (NACE K).

Information in the SES refers to the month of October of each year, while data in the SBS are measured over entire calendar years, i.e., from January to December. To avoid running a regression where information on the dependent variable (collected for the entire year) precedes the recording of the explanatory variables (collected in October), all explanatory variables in equation (1) have been lagged by one year. This way, information on ORU variables is recorded in October in year $t$ and used to explain firm-level productivity during the calendar year $t+1$. The imperfect synchronization of the SBS and SES data might introduce some fuzziness into our estimates since we cannot exclude the occurrence of external events influencing productivity in the intermediate period. This concern could only be completely eliminated if we had firm-level information on the ORU variables for the entire calendar year. This being said, even if this information were available, there is a compelling argument for using asynchronised information on ORU variables: it is difficult to conceive how changes in ORU variables could generate immediate effects, and potential productivity effects are thus more likely to occur after a certain adjustment period. The slightly asynchronised use of SBS and SES is therefore arguably the best option in light of data availability and productivity dynamics.

As a consequence, our sample contains firms that are observed in at least two consecutive years and thus over-represents medium-sized and large firms since the sampling percentages for each firm in our dataset increase with the size of the latter. ${ }^{5}$ Next, we exclude workers and

\footnotetext{
${ }^{5}$ The SES is a stratified sample. The stratification criteria refer respectively to the region (NUTSgroups), the principal economic activity (NACE-groups) and the size of the firm. The sample size in each stratum depends on the size of the firm. Sampling percentages of firms are respectively equal to 10,50 and 100 percent when the number of workers is below 50, between 50 and 99, and above 100 . Within a firm, sampling percentages of employees also depend on size. Sampling percentages of employees reach respectively 100, 50, 25, 14.3 and 10 percent when the number of workers is below 20, between 20 and 49, between 50 and 99, between 100 and 199, and between 200 and 299. Firms employing 300 workers or more have to report information for an absolute number of employees. This number ranges between 30 (for firms with 300 to 349 workers) and 200 (for firms with 12,000 workers or more). To guarantee that firms report information on a representative sample of their workers, they are asked to follow a specific procedure. First, they have to rank their employees in alphabetical order. Next, Statistics Belgium gives them a random letter (e.g., the letter $\mathrm{O}$ ) from which they have to start when reporting information on their employees (following the alphabetical order of workers' names in their list). If they reach the letter $\mathrm{Z}$ and still have to provide information on some of their employees, they have to continue from the letter A in their list. Moreover, firms that employ different categories of workers, namely managers, blue- and/or white-collar workers, have to set up a separate alphabetical list for each of these categories and to report information on a number of workers in these different groups that is proportional to their share in total firm employment. For example, a
} 
firms for which data are missing or inaccurate. ${ }^{6}$ In addition, in order to guarantee that the level of required education is computed on the basis of a sufficient volume of data, we choose to eliminate occupations at ISCO 3-digit level with less than 10 observations. ${ }^{7}$ We also choose to eliminate firms with less than 10 observations, because the use of average values at firm level requires a suitable number of observations. ${ }^{8}$ Finally, we eliminate (a very small number of) firms with more than one NACE 3-digit code (i.e., firms with more than one activity) over the considered period in order to get only one NACE 3-digit code per firm at aggregate level. Our final sample covering the period 1999-2010 consists of an unbalanced panel of 12,290 firm-year-observations from 3,913 firms. It is representative of all mediumsized and large firms in the Belgian private sector, with the exception of large parts of the financial sector (NACE K) and the electricity, gas and water supply industry (NACE D+E).

[Insert Table 1 about here]

\subsection{Descriptive Statistics}

Descriptive statistics of selected variables are presented in Table 1. They show that the annual firm-level value added per worker represents on average 94,435 EUR. The mean number of required years of education at the firm level equals 12.01, while the proportions of over- and under-educated workers stand respectively at around 20 and 28\%. Put differently, average years of over- and under-education within firms are respectively equal to 0.53 and -0.94 . Moreover, we find that around $28 \%$ of employees within firms are women, $52 \%$ are bluecollars, 61\% are prime-age workers (i.e., between 30 and 49 years old), 37\% have at least ten years of tenure, and 16\% are part-time workers (i.e., work less than 30 hours per week). Firms have an average of 250 employees and are essentially concentrated in the following sectors: manufacturing (53\%); wholesale and retail trade, repair of motor vehicles and motorcycles

firm with 300 employees (namely, 60 managers, 180 white-collar workers and 60 blue-collar workers) will have to report information on 30 workers (namely, 6 managers, 18 white-collar workers and 6 blue-collar workers). For more details, see Demunter (2000).

${ }^{6}$ For instance, we eliminate a (very small) number of firms for which the recorded value added was negative.

${ }^{7}$ We did some robustness tests by fixing the threshold at 50 observations. However, given that the number of data points per occupation at the ISCO 3-digit level is quite large, this alternative threshold has little effect on sample size and leaves results (available on request) unaffected.

${ }^{8}$ This restriction is unlikely to affect our results as it leads to a very small drop in sample size. 
(15\%); real estate activities, professional scientific and technical activities, administrative and support service activities (13\%); and construction (9\%).

\section{Results}

\subsection{Overall Specification}

We first estimate equation (1) by OLS with standard errors robust to heteroscedasticity and serial correlation. The results presented in the second column of Table 2 show that lagged productivity has a significant and positive effect on its contemporaneous value. Moreover, an additional year of required education has a significant and positive impact on firm productivity. Firm productivity is estimated to rise by $1.3 \%$ on average when the (one year lagged) required level of education in a firm increases by one year. As for variables of educational mismatch, results show that mean years of over-education have a significant and positive impact on firm productivity, whereas under-education has a negative and significant impact on firm productivity. Firm productivity increases (decreases) on average by 1.8\% $(0.5 \%)^{9}$ the year after a one-unit increase in mean years of over- (under-)education.

[Insert Table 2 about here]

However, these estimates suffer from the fact that time-invariant unobserved workplace characteristics are not controlled for. They can also be inconsistent due to endogeneity of ORU variables. ${ }^{10}$ To control for these potential biases, we first re-estimate equation (1) using the dynamic GMM-SYS estimator. To examine the consistency of our estimates, we apply Hansen's (1982) and Arellano-Bond's (1991) tests. As shown in the third column of Table 2, these tests respectively do not reject the null hypothesis of valid instruments and of no second order autocorrelation. So, we reliably find that current productivity is positively and

\footnotetext{
${ }^{9}$ Note that, given that the measures of mean years of under-education variable are negative, a positive estimated coefficient means that productivity increases if this variable numerically increases by one unit, in other words when under-education decreases by one year.

${ }^{10}$ The FE estimator only controls for the potential bias related to the time-invariant unobserved workplace characteristics. So, only GMM and LP results are further reported. FE results are available on request.
} 
significantly related to its lagged value. ${ }^{11}$ Concerning required education, the coefficient remains significant and suggests that, when the required level of education increases by one year, the productivity rises by $2.3 \%$ the next year. Moreover, coefficients of educational mismatch all remain significant too, which means that firm productivity increases (decreases) on average by $2.3 \%$ (1.1\%) after a one-unit increase in mean years of over- (under-)education.

As a robustness test, we also estimate equation (1) with the LP estimator that relies on an external instrument (i.e., intermediate inputs) to address endogeneity and that controls for firm fixed effects. The results, reported in the fourth column of Table 2, confirm that required and over-education are beneficial for firm productivity. Point estimates indeed suggest that an increase of one year in these variables fosters productivity on average by respectively $2.3 \%$ and $2.6 \%$ the year after. ${ }^{12}$ As regards the coefficient on under-education, it is still significantly negative and suggests that firm's productivity drops on average by $0.7 \%$ following a one-year increase in this variable the year before.

To compare these productivity estimates with those from the wage literature, a series of complementary hypotheses have been tested. Papers using individual wage data typically suggest that the return to required education is superior to that of attained education. In order to investigate whether this is also the case in our set-up, we re-estimate equation (1) using mean years of workers' attained level of education (namely $\frac{1}{m_{j, t}} \sum_{i=1}^{m_{j, t}}$ Attained $_{i, j, t}$, see footnote 2) as main explanatory variable. Results, reported in Appendix Table A.1, are in line with the wage literature. Indeed, both GMM-SYS and LP estimates suggest that the impact of workers' attained education is significantly smaller on firm productivity than that of required education. $^{13}$

Secondly, to test the ORU specification against the Mincer equation (focusing on attained education), it is conventional in the wage literature to examine whether the return to required education differs from that of over- and under-education, respectively. Along the same lines, we test whether $\beta_{2}=\beta_{3}=\beta_{4}$ in equation (1). Results, based on standard t-tests for equality of

\footnotetext{
${ }^{11}$ Interestingly, the GMM coefficient on the lagged dependent variable falls between the OLS and FE estimates (available on request). As highlighted by Roodman (2009), this result supports the appropriateness of our dynamic GMM-SYS specification.

${ }^{12}$ Note that we ran a test of differences between means in order to know whether a significant difference appears between the estimated parameters for each of the two subsamples, where the two parameters are not significantly different under the null hypothesis, while the two parameters are significantly different under the alternative. The results, showing that all coefficients are statistically different, are available on request.

${ }^{13} \mathrm{t}$-tests for equality of regression coefficients are statistically significant at the 5 percent level and reach respectively -52 and -2 for the GMM-SYS and LP estimates.
} 
regression coefficients, suggest that the return to over-education is either not significantly different from that on required education (GMM-SYS estimates) or slightly bigger (LP estimates). ${ }^{14}$ Given that our analysis is performed at the firm-level (which is likely to create some noise with respect to an individual level approach) and that the use of instrumental variables may inflate standard errors of the estimates (i.e. decrease their precision), we interpret these results as evidence in favour of human capital theory (Becker, 1964). In contrast, our findings are more difficult to reconcile with the predictions of the job competition model (Thurow, 1975). Furthermore, standard t-tests show for both types of estimates (GMM-SYS and LP) that the return to under-education (in absolute value) is smaller than that for required education. ${ }^{15}$ This result is in line with the wage literature.

To test the superiority of our ORU specification, we also re-estimated equation (1) including the required education both in level and squared. Results (available on request) confirm the positive (negative) impact of over- (under-) education on firm productivity. Yet, the potential non-linearity in the return to required education is difficult to assess as estimates are subject to a strong multi-colinearity issue (which leads to a negative and non-significant regression coefficient for the required education in level) and do not pass the Hansen and $\mathrm{AR}(2)$ tests (in the GMM-SYS specification).

Finally, to allow for the depreciation of skills, we test the impact of educational mismatch on productivity for young and older generations of workers as outlined in Kampelmann and Rycx (2012). More precisely, we re-estimated equation (1) including as explanatory variables mean years of over- and under-education respectively among young and older workers in each firm. The threshold to separate young from older workers has been fixed at 35 years. GMMSYS and LP estimates are reported in Appendix Table A.2. They show that over-education exerts a significantly positive impact on productivity both among young and older workers. Interestingly, results also show that the return to over-education decreases with workers age. They thus suggest that over-educated workers are more productive all over their career due to additional skills and capabilities acquired through schooling. Yet, they also suggest that these additional skills and capabilities depreciate as time goes by. As regards under-education, results are more mixed. GMM-SYS estimates reveal that years of under-education depress firm productivity only among young workers. LP estimates confirm a negative impact of under-education on productivity but the latter turns out to be non-significant independently of workers age. Overall, findings thus suggest that the negative impact of under-education on

\footnotetext{
${ }^{14}$ Corresponding t-statistics are equal to 0 and -42 .

${ }^{15}$ Corresponding t-statistics are equal to 208 and 314.
} 
productivity decreases with workers age. This may indicate that under-educated workers either succeed to compensate their lack of productivity by additional work experience and training or end up in less demanding jobs as they get older.

\subsection{Interactions with Working Environments}

\subsubsection{Skills Required by the Job}

In this section, we first investigate whether skills required by the job influence the response to educational mismatch. We thus divide our database into two distinct datasets: the first represents firms with essentially “low-skilled jobs” and gathers 7,183 firm-year observations; the second - the rest of the sample - represents firms with essentially "high-skilled jobs" and gathers 5,107 firm-year observations.

[Insert Table 3 about here]

We first test the reliability of the GMM estimates by applying Arellano-Bond's (1991) and Hansen's (1982) previous tests. As shown in Table 3, we do not reject both the null hypothesis of valid instruments and the null hypothesis of no autocorrelation. As shown in the second and third columns of Table 3, current productivity is positively and significantly related to its past value. Results also indicate that required and over-education exert a positive and significant impact on firm productivity in both types of firms. Yet, the magnitude of regression coefficients is found to be significantly bigger among firms with a large fraction of high-skilled jobs. Indeed, following a one unit increase in mean years of required education (over-education) the productivity of firms with a larger share of high-skilled jobs is estimated to increase on average by $3.3 \%$ (7.0\%), whereas the productivity of firms with more lowskilled jobs is found to increase by $2.3 \%$ (3.3\%). Similar results are obtained with the LP estimator. Results reported in columns 4 and 5 of Table 3 indeed confirm that required and over-education are both beneficial for firm productivity and that the effects of the latter are stronger among firms with a large fraction of high-skilled jobs. ${ }^{12}$ As regards under-education, results are more mitigated. In all specifications, point estimates still suggest that undereducation is detrimental for productivity. However, the significance and magnitude of the latter vary according to the estimator under consideration. 


\subsubsection{Technology/Knowledge Intensity}

We now question whether the effects of educational mismatch variables depend on the level of technological/knowledge intensity of the firm. After dividing the dataset into two groups according to the HT/KIS nomenclature, the first step runs the regressions on hightechnology/knowledge firms, which represents 3,888 firm-year observations. The second step runs the regressions on the rest of the dataset, which represents 8,402 firm-year observations concerning low-tech/knowledge firms.

[Insert Table 4 about here]

When relying on the GMM estimates presented in the second and third columns of Table 4, Arellano-Bond's (1991) and Hansen's (1982) tests first show that, in both cases, they reject neither the null hypothesis of valid instruments, nor the null hypothesis of no autocorrelation. The results then show that the level of required education has a positive, significant impact on firm productivity in both cases. Yet, the magnitude of this effect is found to be stronger among high-tech/knowledge intensive firms. As for educational mismatch variables, the results also suggest a stronger positive impact of over-education in high-tech/knowledge firms than in low-tech/knowledge ones. ${ }^{12}$ This means that increasing the level of over-education by one year leads, the next year, to a 5.0\% increase in high-tech/knowledge firms' productivity, i.e., 2.0\% more than in low-tech/knowledge ones. Then, under-education is estimated to decrease productivity by $1.3 \%$ in low-tech/knowledge firms, while the point estimate is nonsignificant in high-tech/knowledge ones.

Turning to LP estimates, the results presented in the fourth and fifth columns of Table 4 also show that the level of required education still has a positive impact on firm productivity in both types of firms and that this effect is more pronounced among high-tech/knowledge intensive firms. They also confirm the stronger impact of over-education in hightech/knowledge firms (as estimated by GMM-SYS), although the gap between both groups decreases, with a point estimate of $2.5 \%$ in high-tech/knowledge firms, compared to an increase of $2.3 \%$ per additional year of over-education in low-tech/knowledge firms. ${ }^{12}$

As regards under-education, no clear pattern can be found for low and hightech/knowledge intensive firms. Indeed, while LP estimates are insignificant in both types of 
environments, GMM-SYS results suggest that under-education affects productivity negatively and significantly but only among low-tech/knowledge intensive firms.

\subsubsection{Uncertainty of the Firm's Economic Environment}

We now investigate whether the relationship between educational mismatch and firm productivity varies if the firm is operating in a more uncertain economic context. The first regression is run on 4,685 firm-year observations concerning firms evolving in a more uncertain economic context. The second regression is run on 7,605 firm-year observations concerning firms evolving in a less uncertain context.

[Insert Table 5 about here]

The results presented in the second and third columns of Table 5 rely on the GMM-SYS estimator. They first appear to be reliable since Arellano-Bond's (1991) and Hansen’s (1982) tests don't reject the null hypothesises of respectively no autocorrelation and valid instruments. The results then show that firm productivity is positively and significantly related to its past value. Moreover, required, over-, and under-education seem to have a stronger impact on productivity when firms are evolving in more uncertainty. More precisely, an increase of one year in the mean years of required education leads to a stronger increase in productivity if the firm operates in uncertainty (3.1\%) than if it operates in a less uncertain environment (2.4\%). Then, when the mean years of over-education increases by one year, firm productivity increases, the next year, by $4.0 \%$ for firms operating in a more uncertain environment, compared to $2.2 \%$ for firms that are evolving in less uncertainty. Finally, an additional year of under-education is estimated to lower productivity by $1.2 \%$ in case of a more uncertain economic context, compared to a drop of $0.9 \%$ when the economic environment is less uncertain. ${ }^{12}$

Turning to LP estimates, results tend to confirm that over-education has a stronger impact on firm productivity when the firm operates in a more uncertain economic context, since the point estimate for the over-education variable is estimated to be $2.7 \%$ in a more uncertain environment and only $2.3 \%$ in a less uncertain environment. ${ }^{12}$ Concerning under-education, LP results are only significant in a more uncertain context with a point estimate of $1.3 \%$, 
suggesting that under-education has a negative impact on firm productivity only in a more uncertain economic environment. ${ }^{16}$

\section{Discussion and Conclusion}

This paper provides first evidence regarding the direct impact of educational mismatch on firm productivity across working environments. More precisely, we explored the way working environments, differentiated by (i) the level of skills required by the job, (ii) the degree of technological/knowledge intensity, and (iii) the uncertainty of the economic context, may influence the relation between educational mismatch variables and productivity. In order to address these issues, we relied on detailed Belgian linked employer-employee panel data covering the period 1999-2010, used an ORU (Over-, Required, and Under-education) specification aggregated at firm level and considered the average firm-level value added per worker as dependent variable. We thus estimated how mean years of over- and undereducation within firms affect the productivity of these firms (conditional on mean years of required education) across different working environments. To do so, we relied on both the dynamic system-GMM estimator developed by Blundell and Bond (1998) and the structural approach suggested by Levinsohn and Petrin (2003).

Controlling for a large set of covariates, simultaneity issues, time-invariant unobserved workplace characteristics and dynamics in the adjustment process of productivity, we found that a higher level of required education impacts significantly and positively firm productivity but also that increasing the level of over- (under-)education fosters (hampers) firm productivity. These results can be easily reconciled with the literature on the wage effects of educational mismatch. Indeed, they support the assumption that over- (under-)educated workers earn more (less) than those who have just the required education for the job because they are more (less) productive than the latter. On the contrary, our results are not in line with the hypothesis that over-educated workers are less productive because of frustration and a lower degree of job satisfaction.

\footnotetext{
${ }^{16}$ We also examined the interaction between the degree of technology/knowledge intensity and the uncertainty of the firm's economic environment. In particular, we compared the return to over-education in hightech/knowledge and low-tech/knowledge intensive firms operating in a more uncertain environment. Estimates reported in Appendix Table A.3 show that the productivity gains from over-education are significantly larger in the former category of firms. Although caution is required as GMM-SYS estimates do not pass the AR(2) test, these results suggest that the wage premium associated to over-education can be interpreted as a risk premium paid by a firm to protect itself against the negative consequences of the uncertainty faced. We thank an anonymous referee for suggesting this interpretation.
} 
As regards the role of working environments, we started by considering the skills required by the job. Our results suggest that over-education exerts a positive and significant impact on productivity whatever the type of skills required by firms. Yet, the impact of over-education is found to be significantly stronger among firms with a larger fraction of high-skilled jobs. Put differently, results suggest that over-educated workers contribute more to firm value added when the latter require higher on the job skills. These findings seem compatible with Brown's (1990) assumption according to which worker's productivity is more "workers' quality" sensitive when jobs require higher skills. At the same time, they also appear to back up the idea that mean workforce quality depends positively upon the share of over-educated workers within firms as the latter i) are more likely to have better unobserved characteristics (as suggested e.g., by Weiss (1995)), and ii) generate intra-firm knowledge spillovers and benefit from positive externalities from highly educated co-workers (as highlighted in e.g., in Booth and Snower (1996)). In contrast, our results do not support the hypothesis that over-educated workers would hamper firm productivity due to frustration potentially exacerbated in a less skills’ demanding environment.

We then studied the influence of the firm's level of technology/knowledge on the ORUproductivity nexus, by distinguishing between high- and low-technology/knowledge firms according to a nomenclature developed by Eurostat. Our results support the assumption of a higher return for over-education in firms qualified as technology/knowledge intensive. This provides evidence that over-educated workers are even more productive in a hightech/knowledge environment, and supports the notion of adaptability developed by Nelson and Phelps (1966), according to whom over-educated workers should benefit from a hightech/knowledge context. The results also support the idea, suggested by Krueger and Kumar (2004), of a higher level of productivity among over-educated, who would benefit from a moving technological environment due to their higher capability to react.

Finally we investigated whether a different response from productivity to educational mismatch appears according to the uncertainty of the economic context. Our results suggest a higher return for over-education in firms that are operating in more uncertain contexts, which tends to confirm the role of over-educated workers in these situations, as developed by Bulmahn and Kräkel (2002), thanks to the improvised and ad hoc solutions they can bring to the firm. They also confirm the predominance of the adaptability criterion developed by Stankiewics (2004), according to which over-educated workers are more flexible, more adaptable, and thus more productive in uncertainty. 
As regards the moderating role of working environments in the effects of under-education on productivity, conclusions are somewhat less clear-cut as results vary across specifications. Yet, a more uncertain economic context is systematically found to accentuate the detrimental effect of under-education on productivity.

It is finally worth mentioning that the three working environments assessed can be related to some extent, as jobs requiring higher skills, high-tech/knowledge firms, and firms that operate in a more uncertain context all correspond to challenging and changing working conditions. A similar trend can thus theoretically be expected, and our empirical results indeed suggest that over-educated workers would be more productive in firms that (i) require higher skills, (ii) rely on high-technological/knowledge processes for their production, and (iii) operate in a more uncertain economic context.

\section{References}

Arellano, M., \& Bond, S. (1991). Some tests of specification for panel data: Monte Carlo evidence and an application to employment equations. Review of Economic Studies, 58, 277-297.

Arellano, M., \& Bover, O. (1995). Another look at the instrumental variable estimation of error-components models. Journal of Econometrics, 68, 29-51.

Autor, D., Katz, L., \& Krueger, A. (1998), Computing inequality: Have computers changed the labor market? Quarterly Journal of Economics, 113, 1169-1213.

Bandura, A. (1986). Social Foundations of Thought and Action: A social Cognitive View. Englewood Cliffs: Prentice-Hall.

Barrick, M., \& Mount, M. (1991). The big five personality dimensions and job performance: A meta-analysis. Personnel Psychology, 44, 1-26.

Bartel, A., \& Sicherman, N. (1998). Technological change and the skill acquisition of young workers. Journal of Labor Economics, 16: 718-755.

Battu, H., Seaman, P., \& Sloane, P. (1999). Overeducation, undereducation and the British labour market. Applied Economics, 31, 1437-1453.

Becker, G. (1964). Human Capital. New York: NBER.

Blanchflower, D., \& Bryson, A. (2010). The wage impact of trade unions in the UK public and private sectors. Economica, 77, 92-109.

Blundell, R., \& Bond, S. (1998). Initial conditions and moment restrictions in dynamic panel data models. Journal of Econometrics, 87, 115-143. 
Booth, A., \& Snower, D. (1996). Acquiring Skills: Market Failures, their Symptoms and Policy Responses. Cambridge: Cambridge University Press.

Brown, C. (1990). Firms' choice of method of pay. Industrial and Labor Relations Review, 43, 165-182.

Büchel, F. (2002). The effects of overeducation on productivity in Germany - The firms' viewpoint. Economics of Education Review, 21, 263-275.

Bulmahn, G., \& Kräkel, M. (2002). Overeducated workers as an insurance device. Labour, 16: 383-402.

Caplan, B. (2003). Stigler-Becker versus Myers-Briggs: Why preference-based explanations are scientifically meaningful and empirically important. Journal of Economic Behaviour \& Organization, 50, 391-405.

Demunter, C. (2000). Structure and distribution of earnings survey. DGSIE Working Paper. Brussels: Belgium.

Dolton, P., \& Silles, M. (2008). The effects of over-education on earnings in the graduate labour market. Economics of Education Review, 27, 125-139.

Duncan, G., \& Hoffman, S. (1981). The incidence and wage effects of overeducation. Economics of Education Review, 1, 75-86.

European Commission (2012). Education and Training - Monitor 2012. Luxembourg: Publications Office of the European Union.

European Union (2009). Council Conclusions of 12 May 2009 on a strategic framework for European cooperation in education and training. Luxembourg: Official Journal C119 of 28.5.2009.

European Union (2012). Employment and Social Developments in Europe 2012. Luxembourg: Publications Office of the European Union.

Eurostat (2012). High-tech Statistics - Statistics Explained. Luxembourg: Eurostat.

Freeman, R. (1976). The Overeducated American. New York: Academic Press.

Green, F., \& Yu, Z. (2010). Overqualification, job dissatisfaction, and increasing dispersion in the returns to graduate education. Oxford Economic Papers, 62, 740-763.

Grunau, P. (2014). The impact of overeducated and undereducated workers on firm-level productivity - First evidence for Germany, mimeo, Institute for Employment Research (IAB), Nuremberg, Germany. Paper presented at the Workshop Firm-level Analysis of Labour Market Issues, Université Catholique de Louvain, Belgium, May 28, 2014.

Hansen, L. (1982). Large sample properties of generalized method of moments estimators. Econometrica, 50, 1029-1054. 
Hartog, J. (2000). Over-education and earnings: Where are we, where should we go? Economics of Education Review, 19, 131-147.

Hersch, J. (1991). Education match and job match. Review of Economics and Statistics, 73, 140-144.

Hogan, J., \& Ones, D. (1997). Conscientiousness and integrity at work. In: R. Hogan, J. Johnson, \& S. Briggs (Eds.), Handbook of Personality Psychology. NY: Academic Press.

Ilmakunnas, P., \& Ilmakunnas, S. (2011). Diversity at the workplace: Whom does it benefit? De Economist, 159: 223-255.

Judge, T., Thoresen, C., Bono, J., \& Patton, G. (2001). The job satisfaction-job performance relationship: A qualitative and quantitative review. Psychological Bulletin, 127, 376-407.

Kampelmann, S., \& Rycx, F. (2012). The impact of educational mismatch on firm productivity: Evidence from linked panel data. Economics of Education Review, 31, 918931.

Krueger, D., \& Kumar, K. (2004). Skill-specific rather than general education: A reason for US-Europe growth differences? Journal of Economic Growth, 9, 167-207.

Lazear, E. (1989). Pay equality and industrial politics. Journal of Political Economy, 97, 561580.

Lazear, E., \& Rosen, S. (1981). Rank-order tournaments as optimum labor contracts. Journal of Political Economy, 89, 841-864.

Levinsohn, J., \& Petrin, A. (2003). Estimating production functions using inputs to control for unobservables. Review of Economic Studies, 70, 317-341.

Mahy, B., Rycx, F., \& Volral, M. (2011). Wage dispersion and firm productivity in different working environments. British Journal of Industrial Relations, 49, 460-485.

Manning, A. (2003). Monopsony in Motion. Imperfect Competition in Labor Markets. Princeton: Princeton University Press.

Marshall, A. (1890). Principles of Economics. New York: Macmillan.

Mavromaras, K., McGuinness, S., O’Leary, N., Sloane, P., \& Fok, Y. (2010). The problem of overskilling in Australian and Britain. The Manchester School, 78, 219-241.

Mavromaras, K., \& McGuinness, S. (2012). Overskilling dynamics and education pathways. Economics of Education Review, 31, 619-628.

McGuinness, S. (2006). Overeducation in the labour market. Journal of Economic Surveys, 20, 387-418.

McGuinness, S., \& Sloane, P. (2011). Labour market mismatch among UK graduates: An analysis using REFLEX data. Economics of Education Review, 30, 130-145. 
McQuaid, R., Raeside, R., Canduela, J., Egdell, V., \& Colin, L. (2012). Engaging Low Skilled Employees in Workplace Learning. UK Commission for Employment and Skills (UKCES), Evidence Report 43.

Mortensen, D. (2003). Wage Dispersion: Why Are Similar Workers Paid Differently. Cambridge (Ma.): MIT Press.

Nelson, R., \& Phelps, E. (1966). Investment in humans, technological diffusion and economic growth. American Economic Review, 56, 69-75.

Olley, S., \& Pakes, A. (1996). The dynamics of productivity in the telecommunications equipment industry. Econometrica, 64, 1263-1297.

Petrin, A., Poi, B., \& Levinsohn, J. (2004). Production function estimation in Stata using inputs to control for unobservables. Stata Journal, 4, 113-123.

Roodman, D. (2009). How to do xtabond2: An introduction to difference and system GMM in Stata. Stata Journal, 9, 86-136.

Rumberger, R. (1987). The impact of surplus schooling on productivity and earnings. Journal of Human Resources, 22, 24-50.

Sattinger, M. (2012). Qualitative Mismatches. Hanover (Ma.): Now Publishers.

Sattinger, M., \& Hartog, J. (2013). Nash bargaining and the wage consequences of educational mismatches. Labour Economics, 23, 50-56.

Sicherman, N. (1991). Overeducation in the labor market. Journal of Labor Economics, 9, 101-122.

Spence, M. (1973). Job market signalling. Quarterly Journal of Economics, 87, 355-374.

Stankiewics, F. (2004). Travail, progrès technique et valorité différentielle : le problème de la sélection des travailleurs. Revue d'Economie Politique, 114, 111-131.

Thurow, L. (1975). Generating Inequality. Mechanisms of Distribution in the U.S. Economy. New York: Basic Books.

Thurow, L. (1979). A job-competition model. In Michael Piore (Ed.) Unemployment and Inflation: Institutionalist and Structuralist Views. New York: Sharpe.

Tsang, M. (1987). The impact of underutilization of education on productivity: A case study of the U.S. bell companies. Economics of Education Review, 6, 239-254.

Tsang, M., Rumberger, R., \& Levin, H. (1991). The impact of surplus schooling on worker productivity. Industrial Relations, 30, 209-228.

Van Beveren, I. (2012). Total factor productivity estimation: A practical review. Journal of Economic Surveys, 26, 98-128. 
Van der Meer, P. (2006). The validity of two education requirement measures. Economics of Education Review, 25, 211-219.

Verhaest, D., \& Omey, E. (2006). The impact of overeducation and its measurement. Social Indicators Research, 77, 419-448.

Verhaest, D., \& Omey, E. (2009). Objective over-education and worker well-being: A shadow price approach. Journal of Economic Psychology, 30, 469-481.

Vroom, V. (1964). Work and Motivation. New York: Wiley.

Weiss, A. (1995). Human capital vs. signalling explanations of wages. Journal of Economic Perspectives, 9, 133-154. 
Table 1. Descriptive Statistics of Selected Variables, 1999-2010

\begin{tabular}{|c|c|c|}
\hline Variables & Mean & Std. Dev. \\
\hline Annual value added per worker ${ }^{\mathrm{a}}(€)$ & 94,435 & 602,856 \\
\hline Required education (years) & 12.01 & 1.36 \\
\hline \multicolumn{3}{|l|}{ Over-education } \\
\hline Percentage of workers & 20.35 & 22.08 \\
\hline Years & 0.53 & 0.62 \\
\hline \multicolumn{3}{|l|}{ Under-education } \\
\hline Percentage of workers & 27.72 & 26.40 \\
\hline Years & -0.94 & 1.03 \\
\hline Workers with 10 years or more of tenure (\%) & 37.44 & 23.75 \\
\hline Women (\%) & 28.33 & 24.64 \\
\hline Blue-collar workers ${ }^{\mathrm{b}}(\%)$ & 52.39 & 35.22 \\
\hline Share of workers $<30$ years & 21.78 & 14.73 \\
\hline Share of workers between 30 and 49 years & 60.89 & 13.79 \\
\hline Share of workers $>49$ years & 17.33 & 12.51 \\
\hline Part-time (\%) & 16.40 & 17.55 \\
\hline Firm size (number of workers) & 250.19 & 448.32 \\
\hline Firm-level collective agreement (\%) & 28.69 & 45.08 \\
\hline \multicolumn{3}{|l|}{ Sector (\%) } \\
\hline Mining and quarrying (B) & 0.68 & \\
\hline Manufacturing (C) & 52.66 & \\
\hline \multicolumn{3}{|l|}{$\begin{array}{l}\text { Electricity, gas, steam and air conditioning } \\
\text { supply; Water supply, sewerage, waste } \\
\text { management and remediation }\end{array}$} \\
\hline activities (D+E) & 0.63 & \\
\hline Construction (F) & 8.85 & \\
\hline $\begin{array}{l}\text { Wholesale and retail trade, } \\
\text { repair of motor vehicles and } \\
\text { motorcycles }(G)\end{array}$ & 15.28 & \\
\hline $\begin{array}{l}\text { Accommodation and food services } \\
\text { activities (I) }\end{array}$ & 1.81 & \\
\hline $\begin{array}{l}\text { Transport and storage ; Information and } \\
\text { communication }(\mathrm{H}+\mathrm{J})\end{array}$ & 5.88 & \\
\hline Financial and insurance activities (K) & 1.59 & \\
\hline $\begin{array}{l}\text { Real estate activities ; Professional, } \\
\text { scientific and technical activities ; } \\
\text { Administrative and support service } \\
\text { activities }(\mathrm{L}+\mathrm{M}+\mathrm{N})\end{array}$ & 12.60 & \\
\hline Number of firm-year observations & & 12,290 \\
\hline
\end{tabular}

Data source:SES-SBS 1999-2010.

Notes: ${ }^{\mathrm{a}}$ At 2004 constant prices. ${ }^{\mathrm{b}}$ The distinction between blue- and white-collar workers is based on the International Standard Classification of Occupations (ISCO-08). Workers belonging to groups 1-5 are considered to be white-collar workers (1: Managers; 2: Professionals; 3: Technicians and associate professionals; 4: Clerical support workers; 5: Services and sales workers), and those from groups 7-9 are considered to be blue-collar workers (7: Craft and related trades workers; 8: Plant and machine operators and assemblers; 9: Elementary occupations). 
Table 2. Educational Mismatch and Productivity (OLS, GMM and LP estimates, 1999-2010)

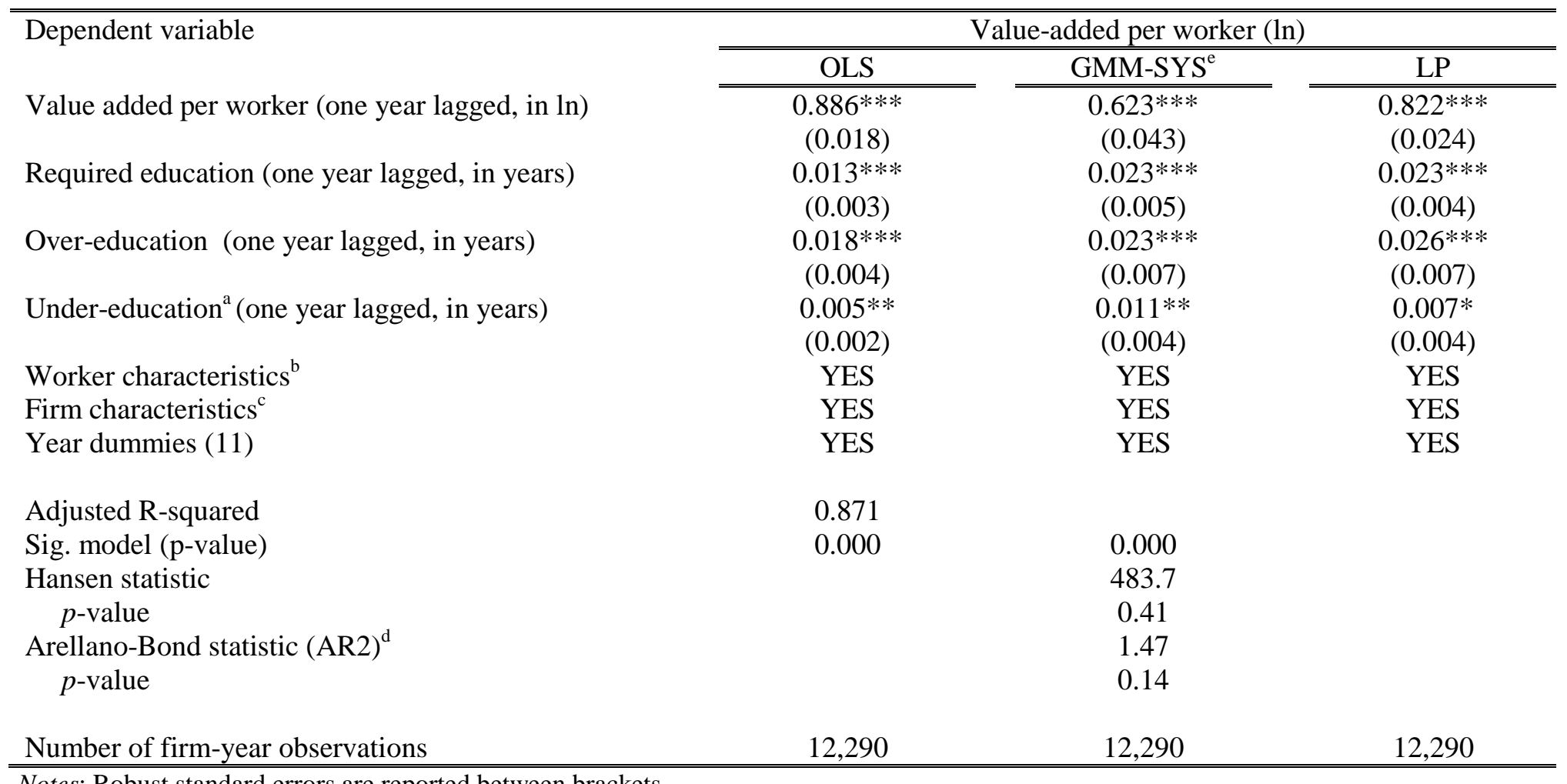

Notes: Robust standard errors are reported between brackets.

${ }^{a}$ By definition, mean years of under-education take negative values in our dataset. Therefore, a positive regression coefficient should be interpreted as follows: when mean years of under-education increase (decrease), i.e., become less (more) negative, productivity rises (decreases).

${ }^{\mathrm{b}}$ Shares of the workforce that: (i) has at least 10 years of tenure, and (ii) is younger than 30 and older than 49 years, respectively. The shares of women, bluecollar and part-time workers as well as the conditional dispersion in hourly wages are also included.

${ }^{\mathrm{c}}$ Sectorial affiliation (8 dummies), number of workers, age of the firm, and level of wage bargaining (1 dummy).

${ }^{\mathrm{d}}$ AR2 displays the test for second-order autocorrelation in the first-differenced errors.

${ }^{\mathrm{e}}$ First and second lags of explanatory variables are used as instruments in the GMM specification, excluding time dummies.

***, **, * significant at the 1,5 and $10 \%$ level, respectively. 
Table 3. Educational Mismatch and Productivity According to Skills Required by the Job (GMM and LP estimates, 1999-2010)

\begin{tabular}{|c|c|c|c|c|}
\hline \multirow[t]{3}{*}{ Dependent variable } & \multicolumn{4}{|c|}{ Value added per worker (ln) } \\
\hline & \multicolumn{2}{|c|}{ GMM-SYS } & \multicolumn{2}{|c|}{ LP } \\
\hline & Low-Skilled $^{\mathrm{e}}$ & High-Skilled $^{\mathrm{f}}$ & Low-Skilled & High-Skilled \\
\hline Value added per worker (one year lagged, in ln) & $\begin{array}{c}0.595^{* * * *} \\
(0.042)\end{array}$ & $\begin{array}{c}0.777 * * * \\
(0.033)\end{array}$ & $\begin{array}{c}0.780 * * * \\
(0.027)\end{array}$ & $\begin{array}{c}0.807 * * * \\
(0.036)\end{array}$ \\
\hline Required education (one year lagged, in years) & $\begin{array}{c}0.023 * * * \\
(0.006)\end{array}$ & $\begin{array}{c}0.033^{* *} \\
(0.014)\end{array}$ & $\begin{array}{c}0.014^{* * *} \\
(0.005)\end{array}$ & $\begin{array}{c}0.033 * * * \\
(0.011)\end{array}$ \\
\hline Over-education (one year lagged, in years) & $\begin{array}{c}0.033^{* * *} \\
(0.008)\end{array}$ & $\begin{array}{c}0.070 * * * \\
(0.024)\end{array}$ & $\begin{array}{c}0.017 * * \\
(0.008)\end{array}$ & $\begin{array}{c}0.040 * * * \\
(0.016)\end{array}$ \\
\hline 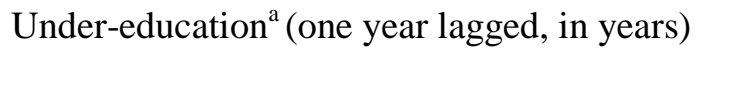 & $\begin{array}{c}0.010 * * \\
(0.004)\end{array}$ & $\begin{array}{c}0.004 \\
(0.018)\end{array}$ & $\begin{array}{c}0.001 \\
(0.004)\end{array}$ & $\begin{array}{l}0.029 * * \\
(0.011)\end{array}$ \\
\hline Worker Characteristics ${ }^{\mathrm{b}}$ & YES & YES & YES & YES \\
\hline Firm Characteristics $^{c}$ & YES & YES & YES & YES \\
\hline Year dummies (11) & YES & YES & YES & YES \\
\hline Sig. model (p-value) & 0.000 & 0.000 & & \\
\hline Hansen statistic & 447.8 & 490.9 & & \\
\hline$p$-value & 0.36 & 0.56 & & \\
\hline Arellano-Bond statistic (AR2) ${ }^{\mathrm{d}}$ & 1.44 & 0.97 & & \\
\hline$p$-value & 0.15 & 0.33 & & \\
\hline Number of firm-year observations & 7,183 & 5,107 & 7,183 & 5,107 \\
\hline
\end{tabular}

Notes: Robust standard errors are reported between brackets.

${ }^{a}$ By definition, mean years of under-education take negative values in our dataset. Therefore, a positive regression coefficient should be interpreted as follows: when mean years of under-education increase, i.e., become less negative, productivity rises, and vice versa.

${ }^{\mathrm{b}}$ Share of the workforce that: (i) has at least 10 years of tenure, and (ii) is younger than 30 and older than 49 years, respectively. The share of women, blue-collar and part-time workers as well as the conditional dispersion in hourly wages are also included.

${ }^{\mathrm{c}}$ Sectorial affiliation (8 dummies), number of workers, age of the firm, and level of wage bargaining (1 dummy).

${ }^{\mathrm{d}}$ AR2 displays the test for second-order autocorrelation in the first-differenced errors.

${ }^{\mathrm{e}}$ First and second lags of explanatory variables are used as instruments in the GMM specification, excluding time dummies.

${ }^{\mathrm{f}}$ Second and third lags of explanatory variables are used as instruments in the GMM specification, excluding time dummies.

$* * *, * *, *$ significant at the 1,5 and $10 \%$ level, respectively. 
Table 4. Educational Mismatch and Productivity According to Technology/Knowledge Intensity (GMM and LP estimates, 1999-2010)

\begin{tabular}{|c|c|c|c|c|}
\hline \multirow[t]{3}{*}{ Dependent variable } & \multicolumn{4}{|c|}{ Value added per worker (ln) } \\
\hline & \multicolumn{2}{|c|}{ GMM-SYS } & \multicolumn{2}{|c|}{$\mathrm{LP}$} \\
\hline & $\begin{array}{c}\text { Low- } \\
\text { Tech/Knowledge } \\
\text { Intensity }^{\mathrm{e}} \\
\end{array}$ & $\begin{array}{c}\text { High- } \\
\text { Tech/Knowledge } \\
\text { Intensity } \\
\end{array}$ & $\begin{array}{c}\text { Low- } \\
\text { Tech/Knowledge } \\
\text { Intensity } \\
\end{array}$ & $\begin{array}{c}\text { High- } \\
\text { Tech/Knowledge } \\
\text { Intensity } \\
\end{array}$ \\
\hline Value added per worker (one year lagged, in ln) & $\begin{array}{c}0.535^{* * *} \\
(0.074)\end{array}$ & $\begin{array}{c}0.758 * * * \\
(0.037)\end{array}$ & $\begin{array}{c}0.795 * * * \\
(0.031)\end{array}$ & $\begin{array}{c}0.821 * * * \\
(0.031)\end{array}$ \\
\hline Required education (one year lagged, in years) & $\begin{array}{c}0.025 * * * \\
(0.007)\end{array}$ & $\begin{array}{c}0.034 * * \\
(0.014)\end{array}$ & $\begin{array}{c}0.017 * * * \\
(0.005)\end{array}$ & $\begin{array}{c}0.027 * * * \\
(0.008)\end{array}$ \\
\hline Over-education (one year lagged, in years) & $\begin{array}{c}0.030 * * * \\
(0.008)\end{array}$ & $\begin{array}{l}0.050 * \\
(0.028)\end{array}$ & $\begin{array}{c}0.023 * * * \\
(0.007)\end{array}$ & $\begin{array}{l}0.025 * \\
(0.013)\end{array}$ \\
\hline 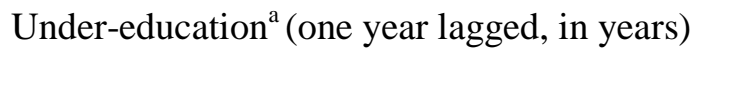 & $\begin{array}{c}0.013^{* * *} \\
(0.005)\end{array}$ & $\begin{array}{l}-0.004 \\
(0.015)\end{array}$ & $\begin{array}{c}0.004 \\
(0.003)\end{array}$ & $\begin{array}{c}0.016 \\
(0.010)\end{array}$ \\
\hline Worker Characteristics ${ }^{\mathrm{b}}$ & YES & YES & YES & YES \\
\hline Firm Characteristics $^{\mathrm{c}}$ & YES & YES & YES & YES \\
\hline Year dummies (11) & YES & YES & YES & YES \\
\hline Sig. model (p-value) & 0.000 & 0.000 & & \\
\hline Hansen statistic & 596.0 & 337.1 & & \\
\hline$p$-value & 0.49 & 0.43 & & \\
\hline Arellano-Bond statistic (AR2) ${ }^{\mathrm{d}}$ & 1.63 & 0.42 & & \\
\hline$p$-value & 0.10 & 0.68 & & \\
\hline Number of firm-year observations & 8,402 & 3,888 & 8,402 & 3,888 \\
\hline
\end{tabular}

Notes: Robust standard errors are reported between brackets.

${ }^{a}$ By definition, mean years of under-education take negative values in our dataset. Therefore, a positive regression coefficient should be interpreted as follows: when mean years of under-education increase, i.e., become less negative, productivity rises, and vice versa.

${ }^{\mathrm{b}}$ Share of the workforce that: (i) has at least 10 years of tenure, and (ii) is younger than 30 and older than 49 years, respectively. The share of women, blue-collar and part-time workers as well as the conditional dispersion in hourly wages are also included.

${ }^{\mathrm{c}}$ Sectorial affiliation (8 dummies), number of workers, age of the firm, and level of wage bargaining (1 dummy).

${ }^{\mathrm{d}}$ AR2 displays the test for second-order autocorrelation in the first-differenced errors.

e First and third lags of explanatory variables are used as instruments in the GMM specification, excluding time dummies.

${ }^{\mathrm{f}}$ Fourth and fifth lags of explanatory variables are used as instruments in the GMM specification, excluding time dummies.

$* * *, * *, *$ significant at the 1,5 and $10 \%$ level, respectively. 
Table 5. Educational Mismatch and Productivity According to Economic Environment Uncertainty (GMM and LP estimates, 1999-2010)

\begin{tabular}{|c|c|c|c|c|}
\hline \multirow[t]{3}{*}{ Dependent variable } & \multicolumn{4}{|c|}{ Value added per worker (ln) } \\
\hline & \multicolumn{2}{|c|}{ GMM-SYS } & \multicolumn{2}{|c|}{$\mathrm{LP}$} \\
\hline & $\begin{array}{c}\text { Less } \\
\text { Uncertain }^{\mathrm{e}} \\
\end{array}$ & $\begin{array}{c}\text { More } \\
\text { Uncertain }\end{array}$ & $\begin{array}{c}\text { Less } \\
\text { Uncertain } \\
\end{array}$ & $\begin{array}{c}\text { More } \\
\text { Uncertain }\end{array}$ \\
\hline Value added per worker (one year lagged, in ln) & $\begin{array}{c}0.693 * * * \\
(0.054)\end{array}$ & $\begin{array}{c}0.637 * * * \\
(0.070)\end{array}$ & $\begin{array}{c}0.812 * * * \\
(0.027)\end{array}$ & $\begin{array}{c}0.796 * * * \\
(0.045)\end{array}$ \\
\hline Required education (one year lagged, in years) & $\begin{array}{c}0.024 * * * \\
(0.007)\end{array}$ & $\begin{array}{c}0.031^{* * *} \\
(0.009)\end{array}$ & $\begin{array}{c}0.021^{* * *} \\
(0.005)\end{array}$ & $\begin{array}{c}0.022 * * \\
(0.010)\end{array}$ \\
\hline Over-education (one year lagged, in years) & $\begin{array}{c}0.022 * * \\
(0.009)\end{array}$ & $\begin{array}{c}0.040 * * * \\
(0.012)\end{array}$ & $\begin{array}{c}0.023^{* * *} \\
(0.008)\end{array}$ & $\begin{array}{c}0.027^{* *} \\
(0.013)\end{array}$ \\
\hline Under-education $^{\text {a }}$ (one year lagged, in years) & $\begin{array}{l}0.009 * \\
(0.006)\end{array}$ & $\begin{array}{l}0.012 * \\
(0.007)\end{array}$ & $\begin{array}{c}0.005 \\
(0.004)\end{array}$ & $\begin{array}{l}0.013^{*} \\
(0.007)\end{array}$ \\
\hline Worker Characteristics ${ }^{\mathrm{b}}$ & YES & YES & YES & YES \\
\hline Firm Characteristics $^{c}$ & YES & YES & YES & YES \\
\hline Year dummies (11) & YES & YES & YES & YES \\
\hline Sig. model (p-value) & 0.000 & 0.000 & & \\
\hline Hansen statistic & 679.0 & 457.0 & & \\
\hline$p$-value & 0.19 & 0.20 & & \\
\hline Arellano-Bond statistic (AR2) ${ }^{\mathrm{d}}$ & 1.27 & 1.55 & & \\
\hline$p$-value & 0.20 & 0.12 & & \\
\hline Number of firm-year observations & 7,605 & 4,685 & 7,605 & 4,685 \\
\hline
\end{tabular}

Notes: Robust standard errors are reported between brackets.

${ }^{a}$ By definition, mean years of under-education take negative values in our dataset. Therefore, a positive regression coefficient should be interpreted as follows: when mean years of under-education increase, i.e., become less negative, productivity rises, and vice versa.

${ }^{\mathrm{b}}$ Share of the workforce that: (i) has at least 10 years of tenure, and (ii) is younger than 30 and older than 49 years, respectively. The share of women, blue-collar and part-time workers as well as the conditional dispersion in hourly wages are also included.

${ }^{\mathrm{c}}$ Sectorial affiliation (8 dummies), number of workers, age of the firm, and level of wage bargaining (1 dummy).

${ }^{\mathrm{d}}$ AR2 displays the test for second-order autocorrelation in the first-differenced errors.

${ }^{\mathrm{e}}$ First and third lags of explanatory variables are used as instruments in the GMM specification, excluding time dummies.

${ }^{\mathrm{f}}$ First and second lags of explanatory variables are used as instruments in the GMM specification, excluding time dummies.

***, **, * significant at the 1,5 and $10 \%$ level, respectively. 
Table A.1. Attained Education and Productivity (GMM and LP estimates, 1999-2010)

\begin{tabular}{|c|c|c|}
\hline \multirow[t]{2}{*}{ Dependent variable } & \multicolumn{2}{|c|}{ "Value-added per worker (ln) } \\
\hline & GMM-SYS $^{\mathrm{d}}$ & LP \\
\hline Value added per worker (one year lagged, in ln) & $\begin{array}{c}0.631^{* * *} \\
(0.048)\end{array}$ & $\begin{array}{c}0.933 * * * \\
(0.026)\end{array}$ \\
\hline Attained education (one year lagged, in years) & $\begin{array}{c}0.020 * * * \\
(0.004)\end{array}$ & $\begin{array}{c}0.013 * * * \\
(0.003)\end{array}$ \\
\hline Worker characteristics $^{\mathrm{a}}$ & YES & YES \\
\hline Firm characteristics ${ }^{\mathrm{b}}$ & YES & YES \\
\hline Year dummies (11) & YES & YES \\
\hline Adjusted R-squared & & \\
\hline Sig. model (p-value) & 0.000 & \\
\hline Hansen statistic & 754.06 & \\
\hline$p$-value & 0.42 & \\
\hline Arellano-Bond statistic $(\mathrm{AR} 2)^{\mathrm{C}}$ & 1.65 & \\
\hline$p$-value & 0.10 & \\
\hline Number of firm-year observations & 12,290 & 12,290 \\
\hline
\end{tabular}

Notes: Robust standard errors are reported between brackets.

${ }^{a}$ Shares of the workforce that: (i) has at least 10 years of tenure, and (ii) is younger than 30 and older than 49 years, respectively. The shares of women, bluecollar and part-time workers as well as the conditional dispersion in hourly wages are also included.

${ }^{\mathrm{b}}$ Sectorial affiliation (8 dummies), number of workers, age of the firm, and level of wage bargaining (1 dummy).

${ }^{c}$ AR2 displays the test for second-order autocorrelation in the first-differenced errors.

${ }^{\mathrm{d}}$ First and fourth lags of explanatory variables are used as instruments in the GMM specification, excluding time dummies.

$* * *, * *, *$ significant at the 1,5 and $10 \%$ level, respectively. 
Table A.2.- Educational Mismatch and Productivity According to Workers’ Age

(GMM and LP estimates, 1999-2010)

\begin{tabular}{|c|c|c|}
\hline \multirow[t]{2}{*}{ Dependent variable } & \multicolumn{2}{|c|}{$\begin{array}{c}\text { Value added per worker (ln) } \\
\end{array}$} \\
\hline & $\mathrm{GMM}^{\mathrm{e}}$ & LP \\
\hline $\begin{array}{l}\text { Value added per worker } \\
\text { (one year lagged, in ln) }\end{array}$ & $\begin{array}{c}0.652 * * * \\
(0.042)\end{array}$ & $\begin{array}{c}0.828 * * * \\
(0.015)\end{array}$ \\
\hline Required education & $0.031^{* * *}$ & $0.028 * * *$ \\
\hline (one year lagged, in years) & $(0.006)$ & $(0.007)$ \\
\hline Over-education among young workers & $0.029 *$ & $0.053 * * *$ \\
\hline (one year lagged, in years) & $(0.016)$ & $(0.017)$ \\
\hline Over-education among older workers & $0.017 * *$ & $0.010 * *$ \\
\hline (one year lagged, in years) & $(0.008)$ & $(0.004)$ \\
\hline Under-education among young workers $^{\mathrm{a}}$ & $0.021 * *$ & 0.0002 \\
\hline (one year lagged, in years) & $(0.010)$ & $(0.008)$ \\
\hline Under-education among older workers $^{\mathrm{a}}$ & 0.009 & 0.009 \\
\hline (one year lagged, in years) & $(0.007)$ & $(0.007)$ \\
\hline Worker Characteristics ${ }^{\mathrm{b}}$ & YES & YES \\
\hline Firm Characteristics ${ }^{c}$ & YES & YES \\
\hline Year dummies (11) & YES & YES \\
\hline Sig. model (p-value) & 0.000 & \\
\hline Hansen statistic & 797.62 & \\
\hline$p$-value & 0.12 & \\
\hline Arellano-Bond statistic (AR2) ${ }^{\mathrm{d}}$ & 1.68 & \\
\hline$p$-value & 0.10 & \\
\hline Number of & 12,290 & 12,290 \\
\hline
\end{tabular}

Notes: Robust standard errors are reported between brackets. Computation based on methodology outlined in Kampelmann and Rycx (2012).

${ }^{\mathrm{a}}$ By definition, mean years of under-education take negative values in our dataset. Therefore, a positive regression coefficient should be interpreted as follows: when mean years of under-education increase (decrease), i.e., become less (more) negative, productivity rises (decreases).

${ }^{b}$ Shares of the workforce that (i) has at least 10 years of tenure, and (ii) is younger than 30 and older than 49 years, respectively. The shares of women, bluecollar and part-time workers as well as the conditional dispersion in hourly wages are also included. ${ }^{\mathrm{c}}$ Sectorial affiliation (8 dummies), number of workers, age of the firm, and level of wage bargaining (1 dummy). ${ }^{\mathrm{d}}$ AR2 displays the test for second-order autocorrelation in the first-differenced errors.

${ }^{\mathrm{e}}$ First and second lags of explanatory variables are used as instruments in the GMM specification, excluding time dummies.

$* * *, * *, *$ significant at the 1,5 and $10 \%$ level, respectively. 
Table A.3. Educational Mismatch and Productivity: High-Tech/Knowledge vs. Low-Tech/Knowledge Intensive Firms in a More Uncertain Economic Environment (GMM and LP estimates, 1999-2010)

\begin{tabular}{|c|c|c|c|c|}
\hline & \multicolumn{4}{|c|}{ Value added per worker (ln) } \\
\hline & \multicolumn{2}{|c|}{ GMM-SYS } & \multicolumn{2}{|c|}{ LP } \\
\hline & $\begin{array}{c}\text { High- } \\
\text { Tech/Knowledge } \\
\text { Intensity } \\
\& \\
\text { More Uncertain }\end{array}$ & $\begin{array}{c}\text { Low- } \\
\text { Tech/Knowledge } \\
\text { Intensity } \\
\& \\
\text { More Uncertain }\end{array}$ & $\begin{array}{c}\text { High- } \\
\text { Tech/Knowledge } \\
\text { Intensity } \\
\& \\
\text { More Uncertain }\end{array}$ & $\begin{array}{c}\text { Low- } \\
\text { Tech/Knowledge } \\
\text { Intensity } \\
\& \\
\text { More Uncertain }\end{array}$ \\
\hline Value added per worker (one year lagged, in ln) & $\begin{array}{c}0.855^{* * *} \\
(0.038)\end{array}$ & $\begin{array}{l}0.702 * * * \\
(0.044)\end{array}$ & $\begin{array}{l}0.790 * * * \\
(0.037)\end{array}$ & $\begin{array}{c}0.834 * * * \\
(0.030)\end{array}$ \\
\hline Required education (one year lagged, in years) & $\begin{array}{c}0.028 * * * \\
(0.011)\end{array}$ & $\begin{array}{c}0.006 \\
(0.012)\end{array}$ & $\begin{array}{c}0.019 * * * \\
(0.005)\end{array}$ & $\begin{array}{l}0.017^{*} \\
(0.009)\end{array}$ \\
\hline Over-education (one year lagged, in years) & $\begin{array}{l}0.023^{*} \\
(0.013)\end{array}$ & $\begin{array}{c}0.022 \\
(0.018)\end{array}$ & $\begin{array}{c}0.021^{* * *} \\
(0.008)\end{array}$ & $\begin{array}{c}0.017 \\
(0.015)\end{array}$ \\
\hline Under-education (one year lagged, in years) & $\begin{array}{c}0.035 \\
(0.025)\end{array}$ & $\begin{array}{l}-0.003 \\
(0.010)\end{array}$ & $\begin{array}{c}0.001 \\
(0.005)\end{array}$ & $\begin{array}{c}0.005 \\
(0.010)\end{array}$ \\
\hline Worker Characteristics ${ }^{\mathrm{b}}$ & YES & YES & YES & YES \\
\hline Firm Characteristics ${ }^{c}$ & YES & YES & YES & YES \\
\hline Year dummies (11) & YES & YES & YES & YES \\
\hline Sig. model (p-value) & 0.000 & 0.000 & 0.000 & 0.000 \\
\hline Hansen statistic & 273.63 & 467.23 & & \\
\hline $\begin{array}{l}\quad p \text {-value } \\
\text { Arellano-Bond statistic (AR2) }\end{array}$ & $\begin{array}{l}0.92 \\
2.45\end{array}$ & $\begin{array}{l}0.25 \\
1.42\end{array}$ & & \\
\hline$p$-value & 0.01 & 0.16 & & \\
\hline Number of firm-year observations & 898 & 3,787 & 898 & 3,787 \\
\hline
\end{tabular}

\footnotetext{
Notes: Robust standard errors are reported between brackets.
}

${ }^{a}$ By definition, mean years of under-education take negative values in our dataset. Therefore, a positive regression coefficient should be interpreted as follows: when mean years of under-education increase, i.e., become less negative, productivity rises, and vice versa. ${ }^{b}$ Share of the workforce that: (i) has at least 10 years of tenure, and (ii) is younger than 30 and older than 49 years, respectively. The share of women, blue-collar and part-time workers as well as the conditional dispersion in hourly wages are also included. ${ }^{c}$ Sectorial affiliation (8 dummies), number of workers, age of the firm, and level of wage bargaining (1 dummy).

${ }^{\mathrm{d}}$ AR2 displays the test for second-order autocorrelation in the first-differenced errors. ${ }^{\mathrm{e}}$ First and third lags of explanatory variables are used as instruments in the GMM specification, excluding time dummies. ${ }^{\mathrm{f}}$ First and second lags of explanatory variables are used as instruments in the GMM specification, excluding time dummies.

***, **, * significant at the 1,5 and $10 \%$ level, respectively. 